\title{
What is good research \& Who is good researcher?
}

Bo-Hyoung Jin

Editor-in-Chief, The Journal of Korean Academy of Oral Health

According to the US Department of HHS regulations, 45 CFR part 46.102, research is defined as a systematic investigation covering research development, testing, and evaluation to develop or contribute to general knowledge. A research is termed 'good' when it comes up with reliable interpretations based on well-designed experiments and adequate controls.

An ideal researcher, who carries out good research with honesty must aim for sound information transmission, accurate reporting of research results, consideration of every possible error, effective coverage of proper resources, and unbiased objectivity.

Also, researchers should always flexible and receptive to recent information. Under rapidly changing research environment, reporting the research results is becoming more crucial, so the researchers should critically select appropriate information and publish it to the research environment.

Recently, the Journal of Korean Academy of Oral health (JKAOH) has been revising some of the instruction of manuscript to improve the quality of the journal, especially in relation to gender regulations. In the health and life science studies, gender innovation research is actively being carried out to increase academic quality and eliminate gender discrimination. The revised gender-related regulations state that the terminology 'sex' and 'gender' should be used accurately according to their purposes.

In general, the term 'sex' should only be used in biological circumstances, whereas 'gender' should be used when describing social, psychological, and cultural issues. Also, in the analysis of the research results, it is necessary to provide a comparative analysis and interpretation of the differences between sex or gender. If the study is carried using only one sex (or gender), the researchers should clearly state appropriate reasons for that.

Gender regulations are based on the fact that the majority of previous research results developed under the male-dominated research environment is not suitable for women. The equal consideration of both gender is the key to any future research in this area. Therefore, the authors of the journals should be tolerant to this change and apply it in the whole research processes: research planning, implementation, analysis, reporting, etc.

Along with gender considerations, actively engaging, cooperative, and tolerant character of researchers is essential to build milestone and correctly drive future research in the field of dental science.

June 2019 


\section{좋은 연구, 좋은 연구자란? \\ 진보형 \\ 대한구강보건학회지 편집이사}

미국 보건복지부 규정(HHS 규정 45 CFR part 46.102)에 따르면, 연구는 연구 개발, 테스트 및 평가를 포함하는 체계적인 조사로, 일 반화 가능한 지식을 개발하거나 기여하도록 고안된 것이라고 정의되어 있다. 또한 좋은 연구는 잘 설계된 실험 디자인과 적절한 통제를 통해 좋은 결과를 해석하는 것이라고 할 수 있다.

이런 좋은 연구를 수행하기 위해 연구자가 지켜야할 핵심 가치에는 정직한 정보 전달을 위한 정직성, 연구 결과의 정확한 보고와 오류 방지를 위한 정확성, 현명하고 낭비없는 자원을 이용하기 위한 효율성, 사실 전달 및 편견없는 객관성이라고 알려져 있다.

이와 더불어 연구자들이 갖추어야 할 다른 역량으로는 정보수용력이라고 할 수 있겠다. 급변하는 연구 주변 환경과 연구 성과의 보고 등이 중요해지면서 연구자 들은 적절한 정보를 선별하고, 변화하는 연구 환경에 맞출 수 있는 역량도 필요하리라고 생각된다.

최근 우리 학회지도 몇 가지 투고 규정의 개정을 통해 보다 더 나은 학술지로 나아가며 변화하는 주변 연구 환경에 발맞추려고 하고 있다. 그 예로 젠더규정의 추가를 들 수 있다. 국내외 의생명과학 연구에서 학술성을 높이고 성차별을 없애는 젠더혁신연구가 활발한데, 개정된 투고 규정의 젠더 관련 내용은 성별(sex)과 젠더(gender)를 구분하여 올바르게 기술하도록 요구하는 것이다. 일반적으로 성별 (sex)은 단순히 생물학적 측면만 고려하지만 젠더(gender)는 사회심리적, 문화적 측면까지를 고려할 때 사용하여야 한다. 또한, 연구결과 분석에서도 남성과 여성으로 구분하여 조사한 연구는 연구 결과를 해석할 때 이 차이점을 비교 분석한 자료를 필수적으로 제시하여야 하 고, 만일 단일 성(sex)을 대상으로 연구한 경우는 학술적으로 타당한 근거를 제시하여야 한다.

젠더 규정은 남성 위주의 연구 환경에 의해 개발된 연구 성과들이 여성에게는 적합하지 않은 점 등을 감안하여 이를 구분하여 차이점 을 살펴나가는 것이다. 이번 우리 학회지가 젠더규정을 추가한 것은 이 분야 연구를 선도하는 역할을 수행하려는 의지가 담긴 것이라고 생각되며, 논문 투고자들도 이와 같은 변화를 빠르게 수용하여, 연구 계획, 수행, 평가 및 보고 등의 일련의 과정에서 이를 적극적으로 활 용하여야 할 것으로 생각된다.

시대 변화에 따라 연구자에게 요청되는 사항도 꼲임없이 변화하지만 좋은 연구를 통해 인류에 기여하는 좋은 연구자로 거듭나기 위 해서는 변화하는 상황에 능동적으로 역할을 수행할 수 있는 자세를 가지는 것도 중요하리라고 생각된다.

2019. 6. 